\title{
Peningkatan Keseimbangan Tubuh Lansia Melalui Senam di Sebuah Balai Pelayanan dan Penyantunan Lansia
}

\author{
Riyeni Dwita Andria ${ }^{1 *}$, Agung Riyadi ${ }^{2}$, Sariman Pardosi $^{3}$ \\ 1,2,3 Jurusan Keperawatan, Poltekkes Kemenkes Bengkulu, Bengkulu, Indonesia \\ *Riyenidwita54@gmail.com
}

\begin{abstract}
The aging process experienced by every human being in the form of physical and psychological changes. Physical changes cause a decrease in the body's ability to maintain balance. Impaired body balance increases the risk of falls and injury to the elderly. Regular exercise can reduce impaired body balance. A good sport for the elderly is gymnastics. The purpose of this study was to determine the effect of gymnastic exercise on the level of balance of the body of the elderly in the Balai service and elderly elderly sponsors. This study uses a Pre-experimental method with one group pretest-posttest design method. A sample of 26 people was obtained with non-probability sampling techniques and purposive sampling techniques. The elderly balance research instruments were collected using a questionnaire and observation sheet. Statistical test using Wilcoxon signed ranks test found that there was an influence of elderly exercise on the level of balance of the elderly body in the service and sponsorship of the elderly in Bengkulu City with a value of $p=0.001(p<\alpha 5 \%)$. Based on the above results it is advisable for the elderly to do gymnastics elderly regularly to prevent disturbance of balance.
\end{abstract}

Keywords: body balance, elderly, gymnastics

\begin{abstract}
Abstrak
Proses menua dialami setiap manusia berupa perubahan fisik dan psikologis. Perubahan fisik menyebabkan penurunan kemampuan tubuh dalam mempertahankan tingkat keseimbangan. Keseimbangan tubuh yang terganggu meningkatkan risiko jatuh dan cedera pada lansia. Senam merupakan bentuk olahraga yang dapat meningkatkan keseimbangan tubuh lansia. Tujuan penelitian ini adalah mengetahui pengaruh olahraga senam terhadap tingkat keseimbangan tubuh lansia. Penelitian ini dilakukan di Balai Pelayanan dan Penyantunan Lansia Kota Bengkulu pada bulan Februari sampai dengan Maret 2018. Menggunakan metode Pre-eksperimental dengan metode one group pretestposttest design. Sampel berjumlah 26 orang didapat dengan teknik non probability sampling dan teknik purposive sampling. Instrumen penelitian menggunakan kuesioner dan lembar observasi. Uji statistik menggunakan Wilcoxon signed ranks test didapatkan bahwa ada pengaruh senam lansia terhadap tingkat keseimbangan tubuh lansia dengan nilai $\mathrm{p}=0,001(\mathrm{p}<\alpha 5 \%)$. Berdasarkan hasil di atas disarankan kepada para staff BPPLU kota Bengkulu untuk melakukan senam secara teratur terhadap lansia untuk mencegah gangguan keseimbangan.
\end{abstract}

Kata kunci: keseimbangan tubuh, lansia, senam 


\section{PENDAHULUAN}

Proses menua merupakan proses yang alami. Lansia mengalami perubahan fisik dan psikologis (Mubarak, 2009). Perubahan yang terjadi pada lansia berupa perubahan sistem tubuh yaitu secara fisik psikologis, sosial dan spiritual (Wiramihardja, T. S, 2014). WHO menyatakan bahwa tahun 2019 proporsi penduduk dunia dengan usia diatas 65 tahun adalah $9 \%$. Seiring dengan meningkatnya usia harapan hidup maka jumlah lansia diperkirakan akan meningkat setiap tahunnya. Populasi lansia di Indonesia pada tahun 2020 berjumlah 28.8 juta orang ( $11,34 \%)$. Persentase lansia di Indonesia dalam waktu lima dekade (19712019) terjadi peningkatan dua kali lipat. Populasi lansia tahun 2019 adalah 9,6 persen (25 juta-an) dan lansia perempuan lebih banyak satu persen dibandingkan lansia laki-laki. Presentase penduduk lansia diprovinsi Bengkulu pada tahun 2019-2020 mengalami peningkatan yaitu tahun 2019 berjumlah 7,52 \% dan pada tahun 2020 berjumlah 7,83\%. (Badan Pusat Statistic, 2020).

Lansia sering mengalami gangguan secara fisik. Gangguan fisik menyebabkan terjadinya penurunan keseimbangan tubuh. Penurunan keseimbangan tubuh pada lansia dapat disebabkan oleh proses keseimbangan tubuh tidak berjalan sempurna. Penyebab dari gangguan keseimbangan tubuh pada lansia adalah terjadinya kemunduran sel-sel karena proses penuaan seperti perubahan atau kemunduran fisik dari perubahan muskuloskeletal yang terjadi pada lansia. Lansia akan mengalami pengurangan massa otot, kakunya jaringan penghubung, dan pengapuran tulang yang menyebabkan Kelemahan otot ekstremitas bawah sehingga terjadinya gangguan keseimbangan tubuh (Darmojo dan Martono, 2008). Gangguan keseimbangan tubuh pada lansia mengakibatkan kekuatan otot menurun serta fungsi visual terganggu (Scott et al., 2006). Kekuatan dan daya tahan otot yang menurun terutama pada ekstremitas bawah menyebabkan turunnya kemampuan fungsional, terutama fungsi mobilitas seperti jalan menjadi lambat, tubuh menjadi kurang seimbang, dan meningkatnya risiko jatuh pada lansia (Utomo, 2010). Gangguan keseimbangan tubuh dapat berdampak langsung pada terjadinya jatuh dan cedera. Hal ini dapat dicegah dengan menjaga keseimbangan tubuh dan mengenal faktor yang dapat menyebabkan gangguan keseimbangan tubuh pada lansia.

Di Indonesia terutama provinsi Bengkulu prevalensi cidera pada penduduk lanjut usia mencapai 9,2\% (Riskesdas,2018). Secara global data gangguan keseimbangan tubuh pada lansia seperti gangguan kognitif sebesar 38,4 \%. Gangguan keseimbangan tubuh dapat menyebabkan cidera atau jatuh pada lansia. Lansia yang mengalami jatuh akibat gangguan keseimbangan tubuh akan menyebabkan injuri dan kecacatan yang dapat menghilangan kemandirian dan berkurangnya kualitas hidup lansia (Salzam,2010). Diprovinsi Bengkulu proporsi cedera pada tahun 2018 adalah 9,2 $\%$, (Riskesdas 2018). Hasil Penelitian yang diakukan oleh $\mathrm{Hu}$ et al (2015) mengatakan bahwa $12,1 \%$ lansia mengalami patah tulang, 33,3\%, terkilir, 45,9\% memar, dan $8,7 \%$ lain-lain. Kaki dan lengan merupakan Bagian tubuh yang paling sering terkena cedera.

Senam lansia merupakan bentuk olahraga yang baik bagi lansia dalam rangka 
menjaga keseimbangan. Senam lansia dapat memadukan gerak dan melatih kekuatan otot serta kelenturan. Senam lansia dilaksanakan dengan diiringi nada berupa serangkaian gerak teratur yang melibatkan semua otot, persendian, dan mudah dilakukan oleh lansia (Atikah, 2010). Senam lansia merupakan salah satu intervensi alternatif untuk mencegah dan mengatasi gangguan keseimbangan tubuh yang dialami lansia. Secara tehnis senam dapat dilaksanakan di ruang terbuka maupun tertutup. Kegiatan senam mengandung unsur rekreasi sehingga dapat menimbulkan perasaan gembira. Gerakan senam melibatkan bagian ekstermitas dan selutuh otot tubuh secara fisiologis akan meningkatkan kekuatan otot. Kekuatan otot yang meningkat akan memberikan pengaruh pada kemampuan tubuh dalam mempertahankan keseimbangan dan mencegah jatuh (Setiati, 2006; Depkes RI, 2005). Gangguan keseimbangan tubuh pada lansia perlu di cegah dan diatasi. Salah satu alternatif tindakan yang dapat dilakukan adalah Senam lansia. Putri (2015) menyatakan bahwa senam tai chi berpengaruh terhadap keseimbangan tubuh dinamis lansia. Gerakan tai chi yang lambat, santai dan menekankan pada kesadaran akan postur tubuh dapat mengendalikan kekuatan otot ekstremitas dan fleksibilitas otot (Kaesner, 2007). Latihan fisik berupa senam yang dilakukan dengan baik, benar, teratur, dan terukur dapat meningkatkan kekuatan otot. Latihan sebaiknya disesuaikan dengan tingkat kebugaran, tingkat kesehatan dan kemampuan aktivitas fisik masing-masing lansia sehingga dapat mengurangi risiko gangguan kelainan tulang dan menyebabkan risiko jatuh (Atikah, 2010; Suarti, 2009).
Berdasarkan hasil survey pada Balai Pelayanan dan Penyantunan Lanjut Usia (BPPLU) kota Bengkulu, tanggal 08 oktober 2017 terhadap 10 orang lansia ditemukan 4 orang $(40 \%)$ lansia yang mengikuti senam memiliki keseimbangan tubuh yang stabil dan dapat melakukan aktifitas sehari hari secara mandiri sedangkan 6 orang $(60 \%)$ lansia yang jarang mengikuti senam atau tidak pernah mengikuti senam memiliki masalah keseimbangan tubuh seperti tidak dapat menjaga keseimbangan tubuh saat terlalu lama berdiri. Hal ini juga diperkuat bahwa belum pernah dilakukan penilaian fungsi keseimbangan dan senam lansia juga jarang dilakukan. Sementara itu, senam lansia diperlukan untuk mengurangi kemungkinan terjadinya jatuh. Maka dari itu perlu dilakukannnya penelitian untuk mengidentifikasi apakah terdapat pengaruh senam terhadap kesimbangan tubuh lansia di Balai Pelayanan dan Penyantunan Lanjut Usia kota Bengkulu.

\section{METODE}

Desain yang digunakan dalam penelitian ini adalah pre-eksperimental dengan metode pretest-posttestone group design. Populasi dalam penelitian ini adalah seluruh lansia yang berada di balai pelayanan dan penyantunan lanjut usia kota Bengkulu berjumlah 61 orang lansia yang memenuhi kriteria inklusi dan eksklusi. Teknik sampling yang digunakan adalah teknik non probability sampling berupa teknik purposive sampling. Sampel yang digunakan berjumlah 26 orang. Penelitian ini dilaksanakan di Balai Pelayanan dan Penyantunan Lanjut Usia kota Bengkulu pada bulan Februari sampai Maret tahun 2018. Penelitian bertujuan untuk mengetahui pengaruh senam lansia 
terhadap tingkat keseimbangan tubuh lansia di Balai Pelayanan dan Penyantunan Lanjut Usia Kota Bengkulu dengan melibatkan satu kelompok subyek.

Data dikumpulkan dengan menggunakan kuesioner dan untuk menilai keseimbangan tubuh dilakukan penilaian langsung dengan menggunakan lembar observasi. Lembar observasi untuk menilai keseimbangan dengan menggunakan Skala Keseimbangan Berg yang sudah ada dan sudah valid. Pengumpulan data dilakukan dari bulan januari 2018 sampai maret 2018. Peneliti melakukan pretest dengan menggunakan lembar observasi Berg Balance Scale sebelum diberikan senam lansia. Kegiatan intervensi berupa senam lansia dilaksanakan dua kali seminggu selama empat minggu berturut turut. Kegiatan posttest untuk menilai keseimbangan tubuh dilaksanakan setelah kegiatan senam pada minggu keempat berakhir. Uji normalitas data menggunakan uji Shapiro-Wilk pada $\alpha$ 5\% menunjukkan data tidak berdistribusi normal. Uji statistik non parametik berupa uji wilcoxon signed ranks test pada $\alpha 5 \%$ (one tail) digunakan untuk mengetahui adanya peningkatan keseimbangan tubuh sebelum dan sesudah diberikan senam lansia.keseimbangan
HASIL

Tabel 1. Distribusi Frekuensi Karakteristik Berdasarkan Usia dan jenis kelamin Di Balai pelayanan dan penyantunan lanjut usia Kota Bengkulu Tahun 2018

\begin{tabular}{llc}
\hline \multicolumn{1}{c}{ Usia } & Frekuensi & Presentasi(\%) \\
\hline $\begin{array}{l}\text { 60- 74 tahun } \\
\text { (elderly) }\end{array}$ & 14 & $53,8 \%$ \\
$\begin{array}{l}75-90 \text { tahun } \\
\text { (old) }\end{array}$ & 12 & $46,2 \%$ \\
\hline \multicolumn{1}{c}{ Jenis kelamin } & Frekuensi & Presentasi(\%) \\
\hline Laki-laki & 19 & $73,1 \%$ \\
\hline Perempuan & 7 & $26,9 \%$ \\
\hline
\end{tabular}

Hasil penelitian menunjukkan bahwa sebagian besar $(53,8 \%)$ lansia berusia 60-74 tahun (elderly dan sebagian besar lansia $(73,1 \%)$ berjenis kelamin laki-laki.

Tabel 2. Distribusi Rata-rata Tingkat keseimbangan tubuh lansia Sebelum dan Sesudah Diberikan senam lansia di Balai pelayanan dan penyantunan lansia Kota Bengkulu Tahun $2018(n=26)$

\begin{tabular}{rccccc}
$\begin{array}{c}\text { Tingkat } \\
\text { keseimbangan }\end{array}$ & Mean & Median & SD & $\begin{array}{c}\text { Min- } \\
\text { Maks }\end{array}$ & $\begin{array}{c}95 \% \text { CI } \\
\text { for Mean }\end{array}$ \\
\hline Sebelum & 39,35 & 40,00 & 2,171 & $32-43$ & $\begin{array}{c}38,47- \\
40,22\end{array}$ \\
Intervensi & & & & & $40,17-$ \\
Sesudah & 40,69 & 41,00 & 1,289 & $37-43$ & 41,21 \\
Intervensi & & & & &
\end{tabular}

Hasil analisa data menunjukkan rata-rata tingkat keseimbangan tubuh lansia sebelum diberikan senam lansia adalah 39,35 dan hasil rata-rata tingkat keseimbangan tubuh lansia setelah diberikan senam lansia adalah 40,69. 
Tabel 3.Perbedaan Pre dan Post Senam Lansia Terhadap Tingkat Keseimbangan

Tubuh Lansia di Balai pelayanan dan penyantunan lanjut usia

Kota Bengkulu Tahun $2018(n=26)$

\begin{tabular}{ccccc}
\hline $\begin{array}{c}\text { Tingkat } \\
\text { keseimbangan }\end{array}$ & $\begin{array}{c}\text { Mean } \\
\text { Rank }\end{array}$ & $\begin{array}{c}\text { Sum } \\
\text { of } \\
\text { Rank }\end{array}$ & Z & $\boldsymbol{p}$ \\
\hline $\begin{array}{c}\text { Sebelum }- \\
\text { Sesudah } \\
\text { Intervensi }\end{array}$ & 10,00 & 190,00 & $-3,897$ & 0,001 \\
\hline
\end{tabular}

Hasil uji statistik menunjukkan bahwa Ho ditolak yang berarti Terdapat Perbedaan signifikan antara tingkat keseimbangan tubuh lansia sebelum dan sesudah diberikan senam ( $p$ $=0,001)$.

\section{PEMBAHASAN}

Hasil penelitian menunjukan bahwa dari 26 responden sebagian besar $(73,1 \%)$ adalah laki-laki. Hasil ini sesuai dengan penelitian Komala (2016) pada 32 responden didapatkan bahwa sebagian besar $(59,4 \%)$ responden di Unit Pelayanan Sosial Lanjut Usia adalah laki laki. Berbeda dengan penelitian Manangkot (2011) pada 27 responden sebagian besar $(74,1 \%)$ responden adalah perempuan yaitu 20 orang, hal ini dikarenakan dari populasi di Panti Sosial Werda Dajan Bingin Sading berjumlah 73 orang lebih dominan perempuan. Penelitian Syafitri (2016) pada 15 responden mengatakan bahwa jenis kelamin lansia mayoritas (66,7\%) perempuan sebanyak 10 orang di pelayanan sosial lanjut usia kota medan.

Hasil penelitian menemukan bahwa sebagian besar $(53,8 \%)$ lansia berusia 60 74 tahun. Menurut WHO usia antara $60-$ 74 tahun termasuk dalam lanjut usia (elderly). Kondisi ini memperlihatkan bahwa makin meningkatnya angka harapan hidup di propinsi Bengkulu. Angka harapan hidup laki-laki 67,28 tahun dan perempuan 71,13 tahun (Badan Pusat Statistic, 2020). Lansia usia 60 - 74 tahun masih dapat melakukan aktifitas dengan baik termasuk mengikuti kegiatan senam dan lansia usia lebih dari 74 tahun sudah mulai mengalami penurunan kemampuan fisik.

Hasil penelitian mengenai pengaruh senam lansia terhadap keseimbangan tubuh menunjukkan terjadinya perubahan yang signifikan. Terjadi peningkatan keseimbangan tubuh setelah dilakukan intervensi berupa senam lansia yang dilakukan pada sore hari selama empat minggu. Hasil penelitian memperlihatkan bahwa rata-rata tingkat keseimbangan tubuh sebelum diberikan senam lansia yaitu 39,35 dan rata-rata tingkat keseimbangan tubuh sesudah dilberikan senam lansia 40,69. Adanya perubahan keseimbangan tubuh juga terlihat dari hasil uji wilcoxon signed ranks test dengan nilai signifikasi $(\mathrm{p}=0,001)$. Hasil ini menunjukan $\mathrm{p}<\alpha 5 \%$ yang berarti Ho ditolak. Senam lansia berpengaruh terhadap tingkat keseimbangan tubuh lansia dibalai pelayanan dan penyantunan lanjut usia kota Bengkulu. Hal ini menguatkan teori suroto (2004) bahwa senam lansia dapat membuat tubuh menjadi segar dan bugar. Senam lansia juga dapat menjaga tulang tetap kuat, system cardiovaskuler berfungsi baik dan jantung berkerja optimal. Tubuh yang bugar disertai system musculoskeletal yang sehat akan berdampak pada peningkatan keseimbangan tubuh lansia. Lansia yang bugar berarti mampu melakukan aktifitas dengan penuh energi sehingga dapat melakukan suatu kegiatan lebih lama. Lansia yang bugar mampu menjaga keseimbangan tubuhnya dengan baik. System musculoskeletal yang sehat 
merupakan factor penting dalam menjaga keseimbangan tubuh. Senam yang dilaksanakan secara teratur membantu lansia mempertahankan kebugaran tubuhnya. tubuh yang bugar membantu lansia mempertahankan keseimbangannya selain faktor sistem muskuloskeletal yang sehat (Khotimah 2014).

Senam bugar lansia berpengaruh terhadap keseimbangan dinamis dan statis lansia (Nugroho, W 2012). Keseimbangan dinamis berarti mampu menjaga keseimbangan dalam posisi tetap sementara keseimbangan statis berarti mampu menjaga keseimbangan ketika bergerak. keseimbangan dinamis dan statis tidak dapat dipisahkan. Dalam aktifitas seharihari tubuh selalu melakukan pergerakan postur untuk menjaga keseimbangan secara bergantian baik statis maupun dinamis. Kemampuan tubuh menyeimbangkan massa tubuh baik dalam keadaan statis maupun dinamis membuat lansia mampu melakukan aktifitas secara efektif dan efisien (Yuliana S, 2014).

Gangguan keseimbangan terjadi pada lansia karena proses keseimbangan tubuh tidak berjalan sempurna. Penyebab lain gangguan keseimbangan tubuh pada lansia adalah terjadinya kemunduran sel-sel karena proses penuaan seperti perubahan atau kemunduran fisik muskoskeletal yang terjadi pada lansia. Lansia mengalami pengurangan massa otot, kakunya jaringan penghubung, dan pengapuran tulang yang menyebabkan kelemahan otot ekstremitas bawah (Darmojo dan Martono, 2008). Senam lansia yang dilaksanakan secara teratur berdampak pada penguatan ekstremitas, otot dan jaringan penghubung yang pada akhirnya akan meningkatkan keseimbangan tubuh lansia.
Lansia secara fisiologis mengalami penurunan kekuatan otot (Scott et al., 2006). Kekuatan otot yang turun disertai penurunan daya tahannya terutama pada anggota gerak bagian bawah menyebabkan kemampuan fungsional terutama kemampuan mobilitas terganggu dan penurunan keseimbangan tubuh (Utomo, 2010). Gangguan keseimbangan dapat menyebabkan terjadinya jatuh dan cedera pada lansia. Kekuatan dan daya tahan otot dapat dipertahankan melalui senam lansia.

Senam sebaiknya dilakukan secara teratur. Senam dapat dilakukan dengan memadukan kelenturan gerak dan latihan meningkatkan kekuatan otot. Gerakan senam lansia dapat merangsang terjadinya kontraksi otot dan sintesis protein berlangsung lebih cepat. Terjadi peningkatan filamen aktin dan miosin di dalam miofibril yang berdampak pada bertambahnya massa otot. Peningkatan massa otot akan disertai peningkatan komponen metabolisme otot. ATP lebih banyak digunakan seiring dengan meningkatnya kekuatan otot. Kekuatan otot yang optimal merupakan factor yang sangat membantu lansia dalam mempertahankan keseimbangan tubuhnya (Guyton, 2007).

Senam lansia melibatkan pergerakan pergerakan semua otot tubuh. Kegiatan senam dapat dilakukan di dalam maupun luar ruangan dan terdapat unsur rekreasi didalamnya. Secara fisiologis senam lansia menyebabkan relaksasi dan kontraksi otot pada system musculoskeletal terutama pada ekstremitas bawah, ekstremitas atas dan batang tubuh. Kontraksi otot pada system musculoskeletat yang terjadi secara teratur akan meningkatkan kekuatan otot sehingga 
keseimbangan tubuh akan terjaga (Setiati, 2006).

Senam lansia merupakan kegiatan yang baik dan aman bagi lansia. Terdapat kegiatan lain yang juga dapat dilakukan oleh lansia yaitu berjalan kaki dan jogging. Aktivitas berjalan kaki atau jogging bila teratur dilaksanakan maka dapat meningkatkan keseimbangan tubuh. Setiap aktivitas tersebut terdapat beberapa kelebihan serta kekurangan yang membuat lansia gagal dalam mencapai tujuan aktivitas fisik yang diharapkan. Jalan kaki labih mudah dan murah dilakukan serta tidak memerlukan peralatan khusus. Jalan kaki secara tehnis memerlukan waktu yang lebih lama dan pelaksanaannya diluar ruangan sehingga bergantung pada cuaca yang baik. Jalan kaki lebih banyak melatih otot ekstremitas bawah. Aktifitas jogging tidak memerlukan alat khusus dan kalori yang dibakar bisa lebih banyak. Jogging kurang baik untuk lansia karena jogging dapat menyebabkan cedera yang disebabkan seringnya benturan pada telapak kaki. Jogging juga secara tehnis dilakukan diluar ruangan sehingga sangat tergantung pada cuaca (Depkes RI, 2010).

Keseimbang tubuh melibatkan tiga system syaraf tubuh yaitu system syaraf pusat, system sensoris dan system neuromusculoskeletal. System syaraf pusat mengkoordinasikan dan mengintegrasikan informasi yang diterima dari system sensoris tentang posisi dan orientasi bagian tubuh terhadap lingkungan. Informasi atau perintah dari system saraf pusat akan direspon oleh System neuromusculoskeletal untuk melakukan gerakan sehingga keseimbangan tubuh akan terjaga (Guccione, et all. 2012). Senam lansia akan merangsang system syaraf sensoris untuk selalu memberikan informasi pada system paraf pusat yang akan memberikan perintah pada system neuromusculoskeletal agar keseimbang tubuh tetap terjaga.

Latihan fisik yang baik, benar, terukur dan teratur dapat mengurangi risiko kelainan tulang. Latihan fisik juga sebaiknya dilakukan sesuai tingkat kebugaran dan kesehatan masing-masing individu (Tobing, 2011). Senam lansia merupakan salah satu aktifitas yang baik bila dilakukan dengan benar, teratur, sesuai dengan tingkat kesehatan dan kebugaran lansia. Senam lansia merupakan olahraga yang melibatkan semua otot tubuh, memadukan gerak dengan nada yang teratur. Senam akan meningkatkan kekuatan otot dan kelenturan tubuh serta mudah dilakukan oleh lansia (Anggiana \& Atikah, 2010).

\section{KESIMPULAN}

Rata - rata tingkat keseimbangan tubuh sebelum diberikan senam lansia 39,50 dan sesudah diberikan senam lansia adalah 40,69. Hasil uji wilcoxon signed ranks test menunjukkan ada perbedaan tingkat keseimbangan tubuh lansia sebelum dan setelah mengikuti senam dengan nilai $(p=0,001)$. Balai pelayanan dan penyantunan lanjut usia kota bengkulu disarankan untuk dapat melaksanakan senam lansia secara rutin dalam rangka meningkatkan keseimbangan tubuh lansia. Penelitian selanjutnya sebaiknya menggunakan desain pre test-post testwith control group, dengan melakukan pengontrolan terhadap variabel lain seperti usia, jenis kelamin, faktor internal,faktor eksternal dan lain-lain sehingga dapat diketahui pengaruh secara mutlak terhadap 
peningkatan keseimbangan tubuh pada lansia.

\section{DAFTAR PUSTAKA}

Adit prasetyo. (2015). Pengaruh senam sehat indonesia terhadap keseimbangan tubuh lansia di sasana panti mulyo desa cantel kabupaten sragen. Fakultas Ilmu Keolahragaan, Universitas Negeri Semarang, Indonesia,2015(online),(journal.unnes.ac .id diakses pada tangga 09 maret 2018).

Anggiyana dan Atikah. (2010). Senam kesehatan. Yogyakarta: Nuha Medica.

Barnedh, Husain. (2006). Penilaian keseimbangan menggunakan skala keseimbangan berg pada lansia di kelompok lansia puskesmas tebet. Tesis. Jakarta: FKUI.

Bapeda SSI. (1996). Buku acuan senam sehat indonesia semarang : Bapeda SSI.

Badan Pusat Statistik, (2020). Angka harapan hidup menurut propinsi. Diakses dari https://www.bps.go.id/linkTableDinam is/view/id/1114 tanggal 24 juli 2020.

Cutlip Scott M., et al, (2006). Effective public relations. Jakarta: Kencana

Darmojo, R. B. \& Martono, H. H. (2008). Geriatri (Ilmu Kesehatan Usia Lanjut). Jakarta: Balai Penerbit FKUI.

Dharmmika, S., Pandji, T. D., \& Laksmi, W. (2005). Pengaruh latihan stabilitas postural terhadap keseimbangan fungsional pada pasien polineuropati diabetic anggota gerak bawah. Tesis. Jakarta: FKUI.

Depkes RI. (2010). Pedoman pembinaan kesehatan usia lanjut bagi petugas kesehatan. Jakarta: Departemen Kesehatan.

Dinkes Provinsi Bengkulu. (2015). Profil kesehatan provinsi bengkulu tahun 2007.
Guyton, A. C. and Hall J. E. (2007). Buku ajar fisiologi kedokteran. Edisi 10. Jakarta: EGC.

Harsuki. (2010). Perkembangan olahraga terkini kajian para pakar. Jakarta: Raja Grafindo.

Hermana. (2007). Kesehatan usia lanjut. Jakarta: Sastra Medika.

Komisi Nasional Lanjut Usia. (2010). Profil Penduduk Lansia Indonesia 2009. Jakarta.

Kahle, N. (2009). The effects of core stability training on balance testing in young. The Universityof Toledo.

Kusnanto. (2007). Peningkatan stabilitas postural pada lansia melalui balance eexercise. Surabaya: PSIK FK UNAIR.

Mubarak. (2009). Ilmu keperawatan komunitas dan aplikasi buku 2. Jakarta: Salemba Medika.

Nugroho, W. (2012). Manfaat olahraga bagi lanjut usia. Jakarta: EGC

Pudjiastuti, S. (2003). Fisioterapi pada Lansia. Jakarta: EGC.

Riskesdas. (2018). Riset kesehatan dasar 2018. Jakarta: Badan penelitian dan pengembangan kesehatan kementerian kesehatan RI.

Setiati. (2006). Gangguan keseimbangan, jatuh, dan fraktur. Buku Ajar Ilmu Penyakit Dalam.Jilid III. Edisi IV. Jakarta: Pusat Penerbitan Departemen Penyakit Dalam FKUI.

Sukawana. (2011). Pengaruh Senam Lansia terhadap Keseimbangan Tubuh pada Lansia dilingkungan Dajan Bingin Sading (online), (https://ojs.unud.ac.id,diakses tanggal 21 september 2017). 
Suroto. (2004). Buku pegangan kuliah pengertian senam, manfaat senam dan urutan gerakan. Semarang: Unit Pelaksana Teknis Mata Kuliah Umum Olahraga Undip.

Tobing, HG. (2011). Prinsip Ilmu Bedah Saraf. Jakarta: Sagung Seto.

Wiramihardja, T. S. (2014). Manfaat latihan tai chi chuan terhadap keseimbangan pada penderita osteoartritis lutut. Tesis. Jakarta: FK

Yuliana, S. (2014). Pelatihan kombinasi core stability exercise dan ankle strategy exercise tidak lebih meningkatkan dari core stability exercise untuk keseimbangan statis pada mahasiswa sl fisioterapi Stikes,, Aisyiyah Yogyakarta. 


\section{HALAMAN INI SENGAJA DI KOSONGKAN}

